\title{
Update on small cell carcinoma and its differentiation from squamous cell carcinoma and other non-small cell carcinomas
}

\author{
William D Travis \\ Department of Pathology, Attending Thoracic Pathologist, Memorial Sloan Kettering Cancer Center, \\ New York, NY, USA
}

\begin{abstract}
Small cell lung cancer (SCLC) comprises $14 \%$ of all lung cancers, and $>\mathbf{3 0} 000$ new cases are diagnosed per year in the United States. SCLC is one of the most distinctive malignancies in the entire field of oncology with characteristic clinical properties, responsiveness to specific chemotherapy, genetic features and a highly reliable pathological diagnosis. SCLC is defined by light microscopy, and the most important stain is a goodquality hematoxylin and eosin (H\&E)-stained section. The vast majority of cases can be diagnosed on H\&E alone; however, in problem cases, immunohistochemistry can be very helpful in making the distinction from other tumors. Cytology is also a powerful tool, often being more definitive than small biopsies with scant tumor cells, crush artifact and/or necrosis. As virtually all SCLCs present in advanced stages, most patients are diagnosed based on small biopsy and cytology specimens. Historically, there has been significant evolution in the histological subclassification of SCLC dating from 1962 when Kreyberg proposed the oat cell and polygonal cell types. The current subclassification recognizes only two subtypes: pure SCLC and combined SCLC. Pathologists need to do their best to make a diagnosis of SCLC or other histological types of lung cancer and this can be achieved in most cases. This review will address some of the diagnostic problems that occur in the minority of cases and outline practical ways to address them. Brief reference will be made to other neuroendocrine lung tumors with an overview of the molecular pathogenesis of this spectrum of tumors. Modern Pathology (2012) 25, S18-S30; doi:10.1038/modpathol.2011.150
\end{abstract}

Keywords: basaloid carcinoma; large cell neuroendocrine carcinoma; small cell carcinoma

Small cell lung cancer (SCLC) comprises $14 \%$ of all lung cancers, and > 30000 new cases are diagnosed per year in the United States. ${ }^{1-4}$ SCLC is one of the most distinctive malignancies in the entire field of oncology with characteristic clinical properties, responsiveness to specific chemotherapy, genetic features and highly reliable pathological diagnosis. ${ }^{3}$ There has even been a specific limited vs extensive staging system proposed for SCLC, although the recent IASLC (International Association for the Study of Lung Cancer) staging project and AJCC/ UICC 7th Edition proposed to use TNM for staging of SCLC. ${ }^{5-7}$ As virtually all SCLCs present in advanced stages, with only $5 \%$ presenting as a solitary coin lesion, most patients are diagnosed based on small

Correspondence: Dr WD Travis, Attending Thoracic Pathologist, Department of Pathology, Memorial Sloan Kettering Cancer Center, 1275 York Ave, New York, NY 10021, USA.

E-mail: travisw@mskcc.org

Received 10 August 2011; revised 29 August 2011; accepted 29 August 2011 biopsy and cytology specimens..$^{3,8,9}$ Virtually all patients with SCLC are cigarette smokers, usually heavy smokers. ${ }^{3}$

Historically, there has been significant evolution in the histological subclassification of SCLC dating from 1962 when Kreyberg proposed the oat cell and polygonal cell types (Table 1). The major lesson learned from this history is that the creation of an 'intermediate' subtype in the 1981 WHO classification was a failure because (1) clinicians were never sure whether these were SCLCs or non-small cell lung carcinomas (NSCLCs); (2) reproducibility was poor among expert pathologists; and (3) it was not clear there was any relevant clinical implication to this category. Hence, despite the continued existence of a small percentage of problem SCLC cases that are difficult to classify, proposals to recreate an 'intermediate' or 'gray-zone' category overlook this important piece of history. The current subclassification recognizes only two subtypes: pure SCLC and combined SCLC. Pathologists need to do their best to make a diagnosis of SCLC or NSCLC. If 
Table 1 History of small cell lung carcinoma (SCLC) subclassification

\begin{tabular}{|c|c|c|c|c|c|}
\hline $\begin{array}{l}\text { Kreyberg } \\
1962^{71}\end{array}$ & WHO $1967^{72}$ & $\begin{array}{l}1973 \text { WP-L } \\
W H O 1981^{34}\end{array}$ & IASLC $1998^{73}$ & WHO/IASLC $1999^{74}$ & WHO $2004^{10}$ \\
\hline \multirow{4}{*}{$\begin{array}{l}\text { Oat cell } \\
\text { Polygonal }\end{array}$} & \multirow{4}{*}{$\begin{array}{l}\text { Lymphocyte-like } \\
\text { Polygonal } \\
\text { Fusiform } \\
\text { Other (containing } \\
\text { squamous and } \\
\text { glandular foci) }\end{array}$} & \multirow{3}{*}{$\begin{array}{l}\text { Oat cell } \\
\text { Intermediate }\end{array}$} & Pure SCLC & \multirow[t]{3}{*}{ SCLC } & \multirow[t]{3}{*}{ SCLC } \\
\hline & & & & & \\
\hline & & & Mixed (with large cells) & & \\
\hline & & Combined & Combined & $\begin{array}{l}\text { Combined SCLC } \\
\text { (containing any other } \\
\text { NSCLC component) }\end{array}$ & $\begin{array}{l}\text { Combined SCLC } \\
\text { (containing any other } \\
\text { NSCLC component) }\end{array}$ \\
\hline
\end{tabular}

IASLC, International Association for the Study of Lung Cancer; WHO, World Health Organization; WP-L, Working Party for Therapy of Lung Cancer.
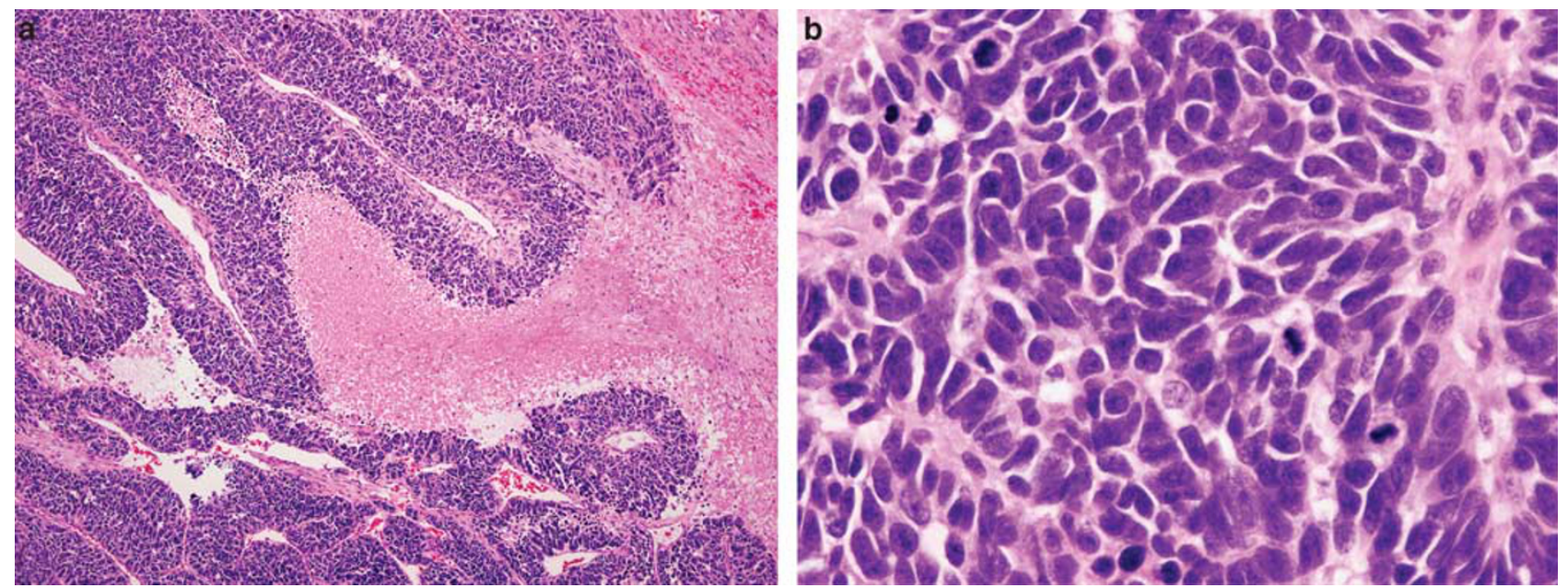

Figure 1 Small cell carcinoma. (a) This tumor consists of diffuse sheets of small malignant cells. Extensive necrosis is present. (b) The tumor consists of dense sheets of small cells with scant cytoplasm, finely granular nuclear chromatin, frequent mitoses and nucleoli are inconspicuous or absent.

there are uncertainties in a difficult case, the challenging issues should be reflected in a comment added to the diagnosis. Some of the causes of these difficulties and practical ways to address them are discussed in this review. Brief reference will be made to other neuroendocrine lung tumors, with an overview of molecular pathogenesis of these tumors.

\section{Histological features}

SCLC is defined by light microscopy as a tumor with cells that have a small size, a round-to-fusiform shape, scant cytoplasm, finely granular nuclear chromatin and absent or inconspicuous nucleoli (Figures 1a and b). ${ }^{10}$ Nuclear molding is frequent. Crush artifact can cause smearing or streaming of nuclear chromatin (Figure 2). Necrosis is frequent and often extensive (Figure 1a). Mitotic rates are high, with an average of 80 mitoses per $2-\mathrm{mm}^{2}$ area (Figure 1b). ${ }^{10-12}$ In small biopsies, mitoses may be difficult to identify and necrosis may be absent because of limited sampling. The tumor usually grows in diffuse sheets, but rosettes, peripheral palisading, organoid nesting, streams, ribbons and rarely, tubules or ductules that fall short of glandular differentiation may be present. ${ }^{11,13}$
Basophilic encrustation of vessel walls by DNA from necrotic tumor cells (nuclear debris also known as the Azzopardi effect) is often seen in necrotic areas. $^{13} \mathrm{~A}$ discohesive pattern of growth may resemble malignant lymphoma, especially when infiltrating mediastinal fat. ${ }^{11}$ Rarely, a pseudopapillary pattern may occur; this is an artifact when perivascular tumor cells remain viable and the intervening tumor is necrotic. ${ }^{11}$ The presence of a very prominent neuroendocrine morphology does not exclude the diagnosis of SCLC. If SCLC has a pure histology, it is classified simply as small cell carcinoma. ${ }^{10}$ SCLC is reliably diagnosed in small biopsies and cytology specimens. In fact, cytology may be more reliable than biopsy in some cases (Figure 3). In biopsies, the most important stain is a good-quality hematoxylin and eosin (H\&E) stain.

\section{Combined Small Cell Carcinoma}

Combined small and large cell carcinoma is defined histologically as a tumor with a mixture of SCLC and at least $10 \%$ larger cells that morphologically qualify as a non-small cell carcinoma (Figure 4). In addition to combined small and large cell carcinoma, one can have combined SCLC with squamous cell, adenocarcinoma, spindle cell ${ }^{14}$ or giant cell 

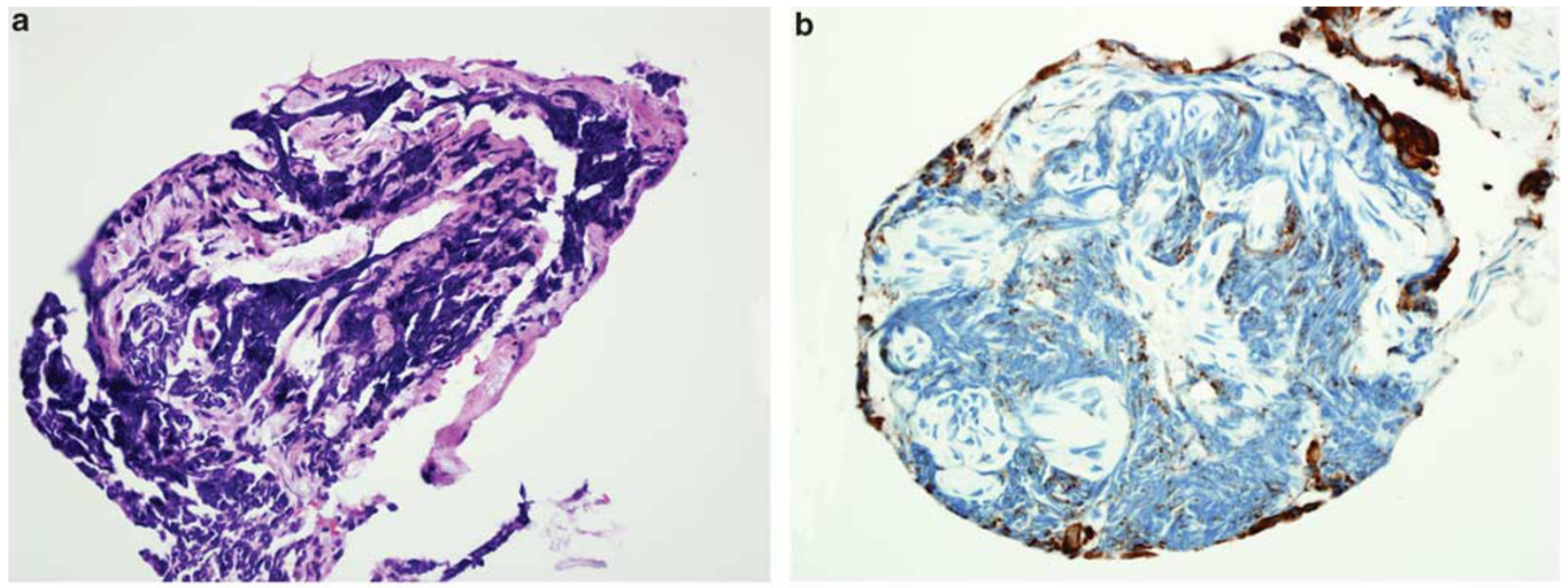

C

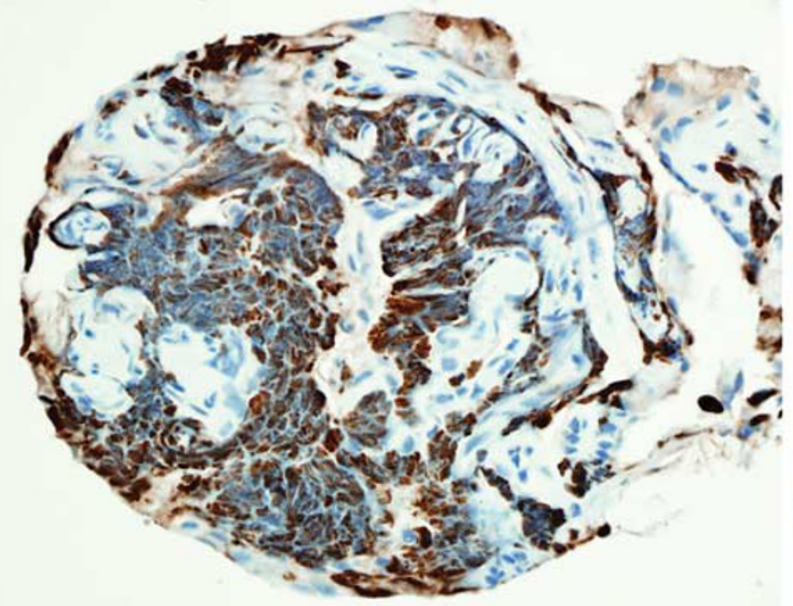

d

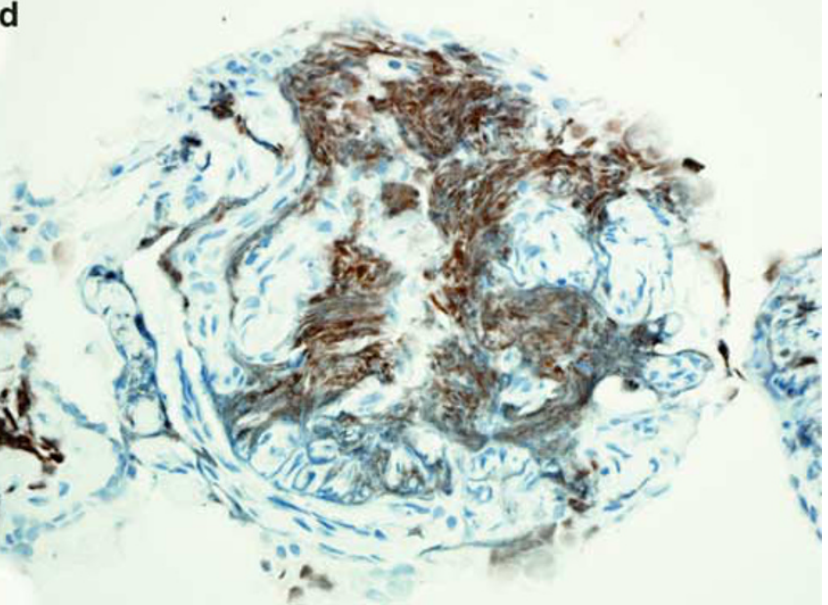

Figure 2 Small cell carcinoma, crush artifact. (a) This tumor shows marked crush artifact. A small area of preserved tumor cells elsewhere and cytology correlation enabled a definitive diagnosis. The following positive immunostains were also helpful in conjunction with a negative CD45: (b) AE1/AE3, (c) Ki-67 and (d) TTF-1.

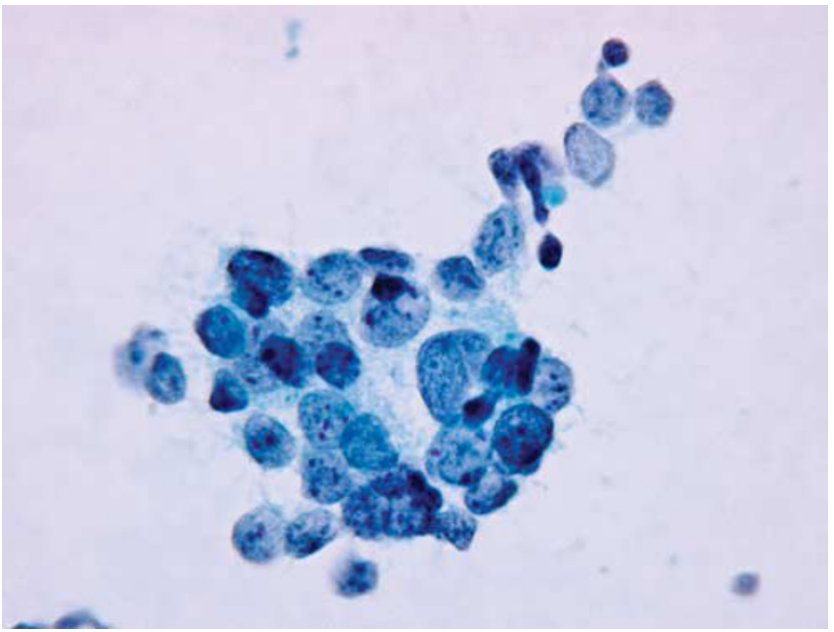

Figure 3 Small cell carcinoma, cytology. This cluster of tumor cells is tightly packed with scant cytoplasm, finely granular nuclear chromatin and nucleoli are absent.

carcinoma. The frequency of combined SCLC varies depending on the tumor sample size, number of histological sections studied, type of specimen

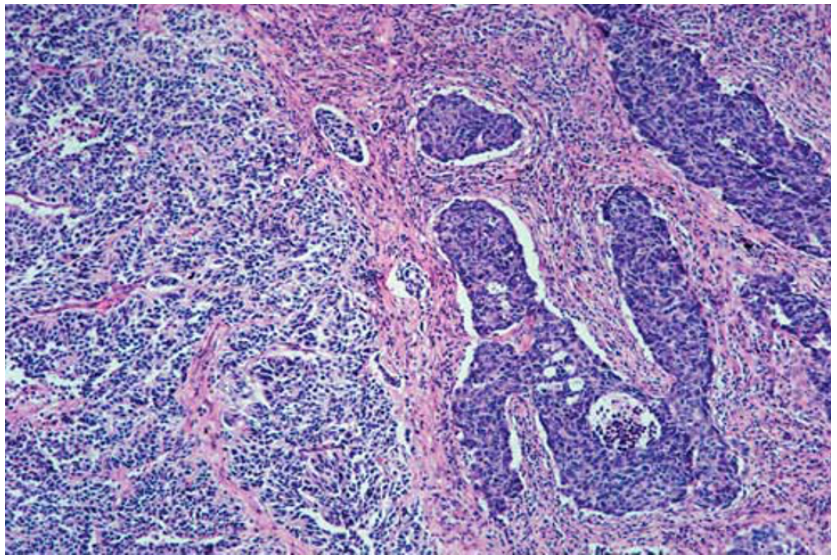

Figure 4 Combined small cell carcinoma and large cell carcinoma. This tumor consists of a mixture of small cell carcinoma (left) and large cell carcinoma (right). The latter has more abundant cytoplasm.

(autopsy vs surgical vs small biopsy) and variation in interpretation. ${ }^{15,16}$ In a series of surgically resected cases, Nicholson et al ${ }^{11}$ found combined 


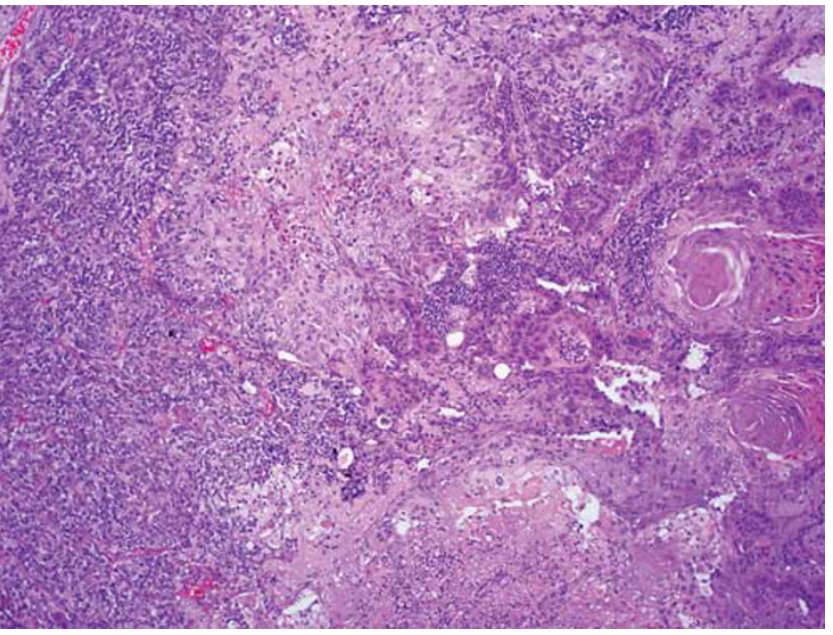

Figure 5 Combined small cell carcinoma and squamous cell carcinoma. This tumor consists of a mixture of small cell carcinoma (left) and squamous cell carcinoma (right).

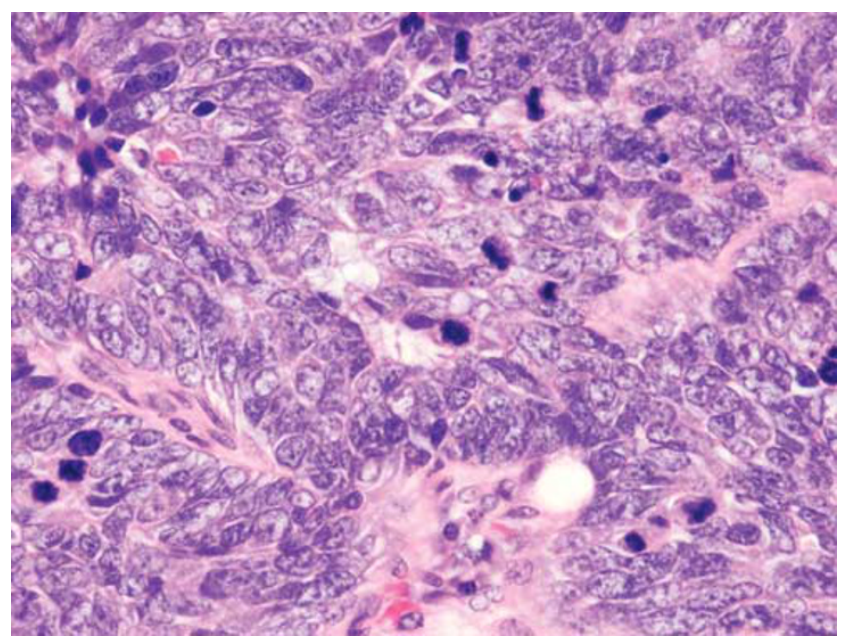

Figure 6 Small cell carcinoma, resected specimen. Tumor cells appear larger than typically seen in small biopsy specimens. However, the cells maintain the morphological features of small cell carcinoma with scant-to-moderate cytoplasm, finely nuclear chromatin and inconspicuous or absent nucleoli.

SCLC in $28 \%$ of cases with $16 \%$ combined SCLC with large cell carcinoma, $9 \%$ with adenocarcinoma and $3 \%$ with squamous cell carcinoma. Although the frequent presence of a few large cells in resected SCLC required setting a minimum criterion of $10 \%$ for combined SCLC and large cell carcinoma, if there is frank adenocarcinoma or squamous cell carcinoma (Figure 5), no such percentage is required. Tumor cells appear larger in surgical specimens of SCLC because they are better fixed than tumor cells in small specimens (Figure 6). ${ }^{11,17}$

\section{Immunohistochemistry}

Although immunohistochemistry is useful in the diagnosis of SCLC, the most important stain is a good-quality H\&E stain. In fact, the diagnosis can be established based on a review of H\&E-stained sections without immunostains in the majority of cases. Hence, immunohistochemistry is required only in problematic cases. Staining for pancytokeratin such as AE1/AE3 helps to demonstrate that the tumor is a carcinoma rather than a lymphoid lesion (Figures 2b and 7a). CK7 and CK20 are not very useful cytokeratins for SCLC diagnosis because only about half stain with CK7 and $<10 \%$ with CK20. ${ }^{18,19}$ Although a 'dot-like' pattern of staining for keratin can occur in SCLC, in many cases this pattern is not seen.

The most useful NE markers include CD56, chromogranin and synaptophysin, which are best used as a pane (Figures $7 \mathrm{~b}$ and $\mathrm{c}$ ). ${ }^{11,20} \mathrm{Up}$ to twothirds of SCLC will be negative for chromogranin and synaptophysin. ${ }^{21}$ CD56 will stain approximately $90-100 \%$ of cases; ${ }^{18,22,23}$ however, it is less specific and interpretation for SCLC diagnosis needs to be performed carefully in the appropriate morphological context. SCLC can stain diffusely and strongly with all three neuroendocrine markers, and this finding should not be used to favor a diagnosis of carcinoid if the morphology is diagnostic, in particular if the tumor has a high mitotic rate and/ or proliferation index. However, neuroendocrine marker staining may be focal or weak and only one or two markers may be positive. In $<10 \%$ of cases, all neuroendocrine markers may be negative and the diagnosis can still be established if the morphology is diagnostic.

In $70-90 \%$ of SCLCs, TTF-1 expression is present (Figures 2d and 7d), ${ }^{10,12,24-28}$ but it can be positive in $44-80 \%$ of extrapulmonary small cell carcinomas as well; hence, it is not useful in determining the primary site of small cell carcinomas. ${ }^{29}$ SCLC show a high proliferation rate by Ki-67, averaging $70-90 \%$ (Figures 2c and 7e). ${ }^{30}$

In cases in which all neuroendocrine markers and TTF-1 are negative, lymphoma, melanoma and basaloid carcinoma should be excluded with positive keratin expression and negative squamous markers such as p63.

Negative immunostains or control slides can reveal morphological details that are obscured by poor-quality $\mathrm{H} \& \mathrm{E}$ stains. In particular, negative immunostains can be useful for evaluating nuclear detail and counting mitoses.

\section{Differential diagnosis}

The differential diagnosis of SCLC encompasses NSCLC (including large cell carcinoma or basaloid squamous cell carcinoma), malignant lymphoma, chronic inflammation, other neuroendocrine lung tumors (including carcinoids and large cell neuroendocrine carcinoma), malignant melanoma and metastatic carcinoma of the breast or prostate and metastatic neuroendocrine carcinomas from other 

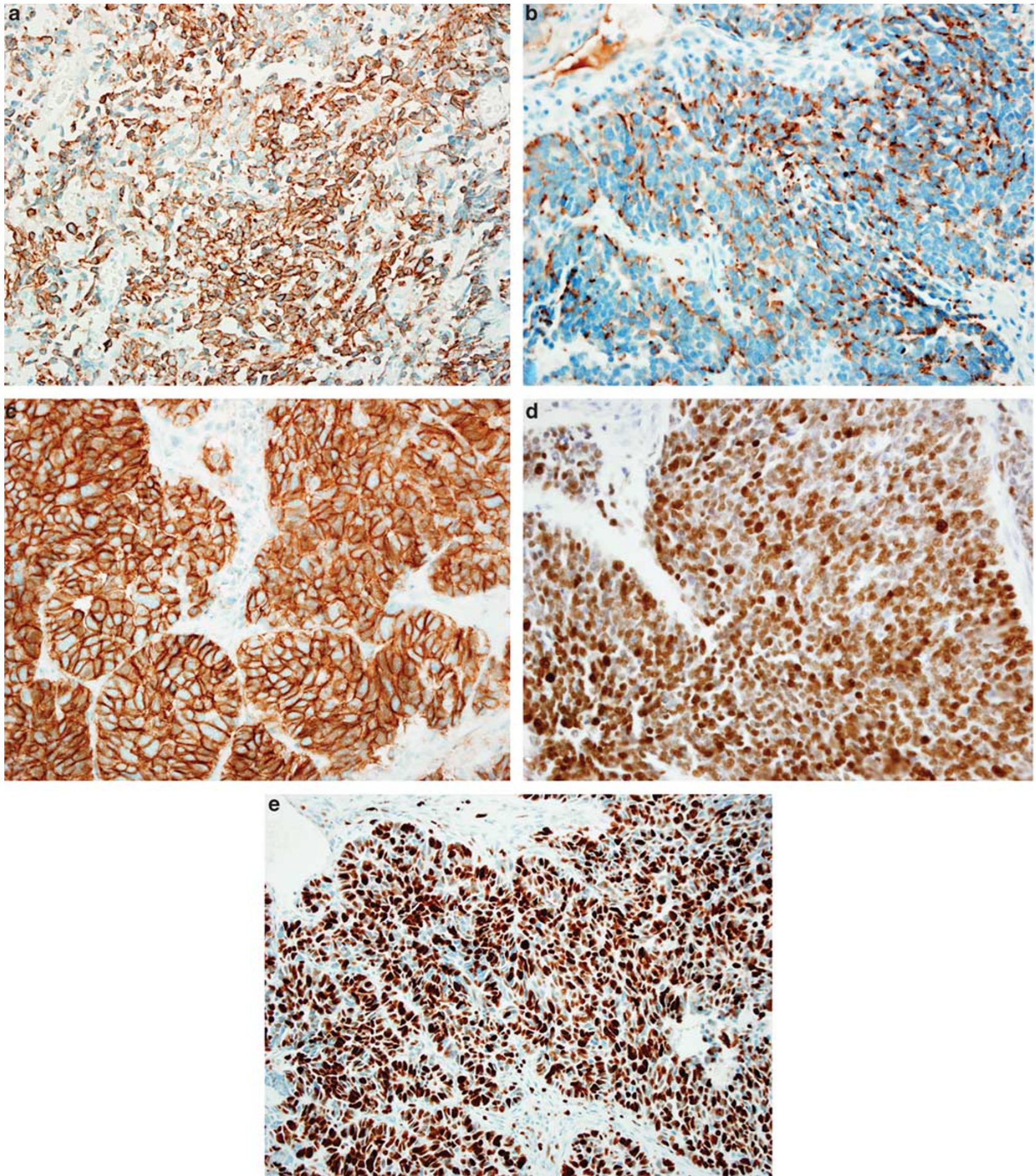

Figure 7 Small cell carcinoma, immunohistochemistry. (a) AE1/AE3 shows positive tumor cell staining. (b) Chromogranin shows positive cytoplasmic staining. (c) CD56 is positive with a membranous pattern. (d) TTF-1 shows diffuse positive nuclear staining. (e) Small cell carcinoma, Ki-67. (Panel d) Ki-67 shows a high proliferation rate with almost 100\% tumor cell staining.

sites. In virtually all cases, the diagnosis of SCLC can be made reliably even with small amounts of tumor tissue or cytology samples. In cases of uncertainty, in which the material is suggestive of SCLC, but not unequivocally diagnostic, it can be useful to use the phrase 'consistent with small cell carcinoma' to communicate to clinicians that there is some limitation in the material that precludes an unqualified diagnosis.

As there are major differences in the therapeutic approach to patients with SCLC vs NSCLC, a frequent question asked of pathologists in the 
Table 2 Light microscopic criteria for distinguishing small cell carcinoma and large cell carcinoma or large cell neuroendocrine carcinoma $^{\text {a }}$

\begin{tabular}{|c|c|c|}
\hline Histological feature & Small cell carcinoma & Large cell carcinoma or $L C N E C^{a}$ \\
\hline Cell size & $\begin{array}{l}\text { Smaller (less than diameter of } 3 \\
\text { lymphocytes) }\end{array}$ & Larger \\
\hline Nuclear/cytoplasmic ratio & Higher & Lower \\
\hline Nuclear chromatin & Finely granular, uniform & $\begin{array}{l}\text { Coarsely granular or vesicular } \\
\text { Less uniform }\end{array}$ \\
\hline Nucleoli & Absent or Faint & $\begin{array}{l}\text { Often (not always) present May } \\
\text { be prominent or faint }\end{array}$ \\
\hline Nuclear molding & Characteristic & Uncharacteristic \\
\hline Fusiform shape & Common & Uncommon \\
\hline Polygonal shape with ample pink cytoplasm & Uncharacteristic & Characteristic \\
\hline Nuclear smear & Frequent & Uncommon \\
\hline Basophilic staining of vessels and stroma & Occasional & Rare \\
\hline
\end{tabular}

LCNEC, large cell neuroendocrine carcinoma.

${ }^{\mathrm{a}}$ This is modified from reference. ${ }^{17}$

interpretation of lung biopsy specimens for the diagnosis of lung cancer is whether the tumor is a SCLC or a NSCLC. As the problem of separating SCLC from large cell carcinoma and LCNEC is very similar, the major criteria in separating both of these tumors from SCLC are summarized in Table 2. The distinction of these tumors from SCLC should not rest on a single feature such as cell size or nucleoli, but incorporation of multiple additional features including nuclear-to-cytoplasmic ratio, nuclear chromatin, nucleoli, nuclear molding, cell shape (fusiform vs polygonal) and hematoxylin vascular staining. ${ }^{17,31}$

Disagreement among expert lung cancer pathologists over the distinction between SCLC and NSCLC may occur in up to $5-7 \%$ of cases. ${ }^{32,33}$ Several factors can contribute to interobserver variability including small crushed biopsy specimens, ischemic changes, poor fixation and poor histological sections that are cut too thick or overstained. In some cases, these problems can be overcome by asking the histology laboratory to recut the block and make a good-quality H\&E-stained section. When a difficult case is encountered, it is helpful to try to reach a local consensus among colleagues, and if this cannot be achieved, it may be helpful to obtain extramural consultation.

There is a spectrum of cellular morphology in SCLC, which includes larger cells that approach the size of large cell carcinoma (Figure 6). Such cases with tumor cell size at the larger end of the spectrum of SCLC used to be referred to as the intermediate subtype under the 1981 WHO classification. ${ }^{34}$ However, this term is no longer accepted. Morphometric data have demonstrated a continuous spectrum of cell size from the smallest SCLC to large cell carcinoma. ${ }^{17,35}$ Thus, tumor cells which fall on the border between SCLC and large cell carcinoma may not be able to be distinguished based on cell size alone and require application of multiple morphological criteria (Table 2). A practical rule is that tumor cells of SCLC should measure approximately the diameter of two to three small resting lymphocytes.

The size of the biopsy specimen can also have an effect on tumor cell size. This observation is based on data that indicate that cells of SCLC appear larger in larger specimens, especially open lung biopsies. ${ }^{11,17}$ As SCLC is diagnosed by small biopsy in $>90 \%$ of cases, most pathologists are not used to seeing this tumor in resected specimens and the threshold for larger cell size needs to be kept in mind when reviewing this tumor in well-fixed open biopsies (Figure 6).

Basaloid variants of large cell or squamous cell carcinoma can be problematic in the differential diagnosis with SCLC. The general morphological criteria for SCLC vs large cell carcinoma summarized in Table 2 can also be useful in this differential diagnosis. However, additional histological, cytological and immunohistochemical features that distinguish SCLC and basaloid carcinoma are summarized in Table 3. The most useful differential histological features are that SCLC more often grows in sheets and shows streaming, and basaloid carcinoma is more likely to show a basement membrane-like or a desmoplastic stroma. Distinguishing immunohistochemical features include expression of squamous markers such as p63 by basaloid carcinomas and TTF-1 or neuroendocrine markers by SCLC. ${ }^{20,26,36}$

\section{Pitfalls in the diagnosis of SCLC}

There are a number of pitfalls in the diagnosis of SCLC. These include lack of cytology-histology correlation, crush artifact, Merkel cell carcinoma, primitive neuroectodermal tumor (PNET), keratinnegative SCLC, diminished proliferation rate in SCLC after chemotherapy and combined SCLC and large cell carcinoma.

SCLC is readily diagnosed by cytology; hence, it is important to correlate the findings in any biopsy that may be paired with a cytology sample. Often in 
Table 3 Differential diagnosis of small cell carcinoma and basaloid carcinoma

\begin{tabular}{|c|c|c|}
\hline Feature & $S C L C$ & Basaloid carcinoma \\
\hline \multicolumn{3}{|l|}{ Histological patterns } \\
\hline Nests/organoid & Common & Common \\
\hline Sheets & Common & Uncommon \\
\hline Trabecular & Possible & Possible \\
\hline Streaming & Common & Rare \\
\hline Rosette-like & Uncommon & Rare \\
\hline $\begin{array}{l}\text { Basement membrane-stroma } \\
\text { (hyaline) }\end{array}$ & Rare & Possible \\
\hline Desmoplastic & Uncommon & Possible \\
\hline \multicolumn{3}{|l|}{ Cytological features } \\
\hline Cell size & Usually $\leqslant$ diameter 3 small resting lymphocytes & Usually $>$ diameter 3 small resting lymphocytes \\
\hline Cell shape & Round to oval or spindled & Round to oval, rarely spindled \\
\hline $\mathrm{N} / \mathrm{C}$ ratio & High & Variable-usually low, can be high \\
\hline Nucleoli & Inconspicuous/absent & Variable-usually present, may be absent \\
\hline Chromatin & Finely granular & Usually vesicular, can be finely granular \\
\hline Abrupt keratinization & $\begin{array}{l}\text { No (unless combined SCLC and squamous cell } \\
\text { carcinoma) }\end{array}$ & Characteristic \\
\hline Mitotic rate & High (70-80 per $2 \mathrm{~mm}^{2}$ ) & High \\
\hline \multicolumn{3}{|l|}{ Immunohistochemical features } \\
\hline AE1/AE3 & Positive & Positive \\
\hline P63 & Negative & Positive \\
\hline $34 \beta \mathrm{E} 12$ (HMWK) & Negative & Positive \\
\hline TTF-1 & Positive: $70-80 \%$ & Negative \\
\hline Chromogranin/synaptophysin & Positive: $60-70 \%$ & Negative \\
\hline CD56 & Positive: $90 \%$ & Negative \\
\hline Ki-67 & High: $70-100 \%$ & High: $70-100 \%$ \\
\hline
\end{tabular}

very challenging biopsies, the diagnosis may be more readily established based on the cytology sample. If this correlation is not made between biopsy and cytology, it is possible to have a diagnosis of SCLC in one specimen and non-small cell carcinoma in the other specimen.

Crush artifact is a frequent finding in small transbronchial or mediastinal biopsy specimens and can make pathological interpretation very difficult (Figure 2a). Tumor cells of SCLC have a tendency to show a streaming artifact, but this can also occur with NSCLC, carcinoid tumors, lymphoma and chronic inflammation. Lymphoid infiltrates, whether due to small lymphocytic lymphoma or chronic inflammation, can be distinguished from SCLC by their discohesive pattern of growth contrasting with the epithelial clustering and nuclear molding of SCLC. Fortunately, the key immunohistochemical stains useful for SCLC diagnosis including keratin (Figure 2b), chromogranin, CD56, Ki-67, TTF-1 (Figure 2d) and CD45 can work even on small crushed biopsies. These stains can help address most of the problems of differential diagnostic considerations in crushed biopsies. Ki-67 proliferation rates can be particularly helpful in distinguishing carcinoid tumors from SCLC in crushed specimens (Figure 2c).$^{30}$ The mitosis-specific marker anti-phosphohistone h3 may also prove to be a useful marker in distinguishing carcinoids from SCLC, but its role in small crushed specimens remains to be determined. ${ }^{37}$

Occasionally, the differential diagnosis with Merkel cell carcinoma or PNET comes into consideration.
Particularly, in a non-smoker, a young patient and the presence of skin lesions or chest wall involvement, these entities may rise to the top of the differential diagnosis. Morphologically, tumor cells of PNET are typically more discohesive and mitotic rates may be relatively low compared with SCLC. PNET tends to be keratin negative or only weakly positive and it tends to stain strongly with immunohistochemical staining for CD99, whereas SCLC is usually positive for pancytokeratin and TTF-1 but CD99 staining is negative or weak. ${ }^{38,39}$ In a metastatic setting, differential with Merkel cell carcinoma can be problematic, but in contrast to SCLC, Merkel cell carcinomas are often CK20 positive, negative for TTF-1 and may express neurofilament protein. ${ }^{18,19,29,40-42}$

A keratin-negative tumor that looks like SCLC should raise the consideration of malignant lymphoma, malignant melanoma, a crushed carcinoid tumor and PNET. Other stains such as lymphoid markers (CD45 or CD20), melanoma markers (S100, HMB-45) a Ki-67 stain and CD99 may be helpful in this differential diagnosis, respectively. It is extremely unusual to encounter a keratin-negative SCLC. When this occurs and other differential diagnostic considerations seem excluded, several keratin antibodies other than CK7/CK20 may be helpful. When all keratins are negative, if the morphology is characteristic and other tumors have been excluded, the finding of TTF-1 and NE marker expression can help support a SCLC diagnosis.

After chemotherapy, the proliferation rate of SCLC may be markedly diminished to levels more fitting for carcinoid tumors (Figure 8). This can be 

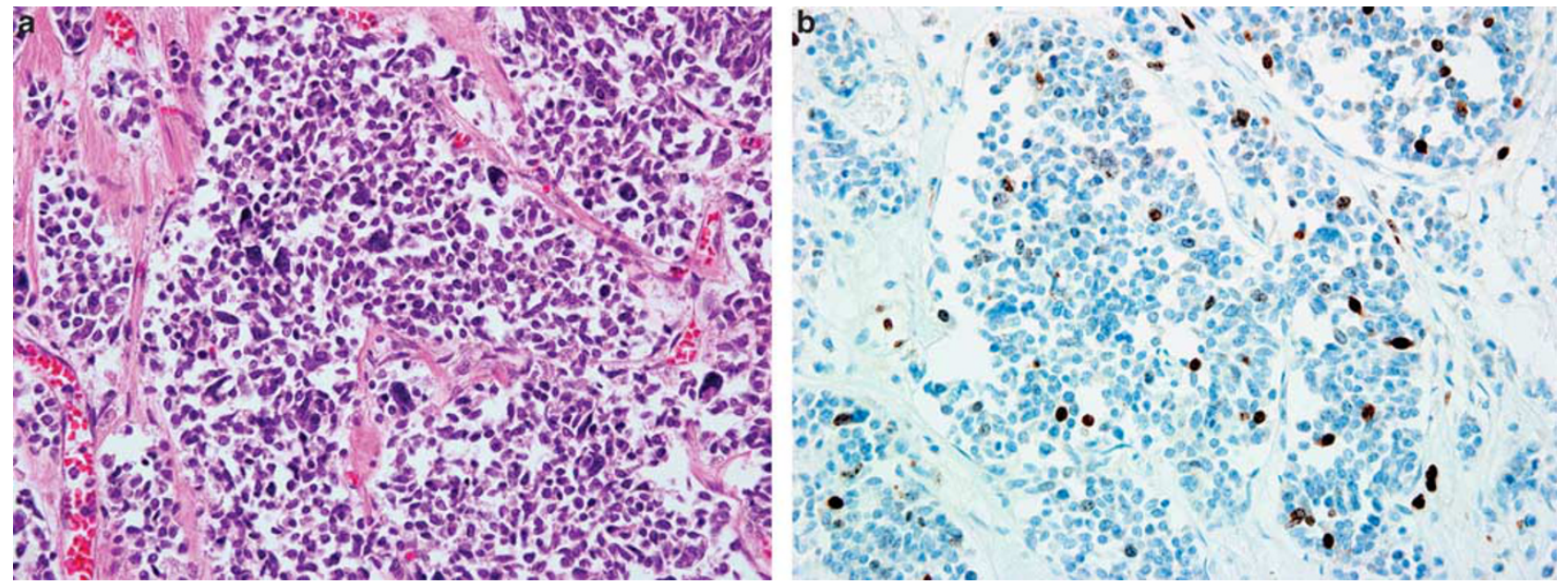

Figure 8 Small cell carcinoma, after chemotherapy. (a) Small cell carcinoma at autopsy with a few large pleomorphic cells. (b) Ki-67 shows a low proliferation rate of $<10 \%$.

confusing in the neoadjuvant setting when tumors are resected after chemotherapy. ${ }^{43}$

Combined SCLC and large cell carcinoma presents a challenge in the differential diagnosis between SCLC vs large cell carcinoma or LCNEC. As up to $16 \%$ of surgically resected cases are combined SCLC and large cell carcinoma, this is an important issue. Pathologists are not trained very well to identify more than a single population of cells in a given tumor; hence, the tendency is to focus on the first field under the microscope and not to keep searching for a second population. Thus, in these combined tumors, sometimes one pathologist will focus on the small cell component and another on the large cell component. In such cases, the entire set of tumor slides and all cellular components should be reviewed. In most combined tumors, the SCLC component is the predominant component. As the presence of a SCLC component will define the therapy for the patient, the most important decision for a pathologist is the determination of whether a SCLC component is present.

It is extremely unusual to encounter SCLC in a never smoker. When this occurs, the diagnosis should be documented very carefully with a thorough immunohistochemical evaluation to exclude lymphoma, melanoma, carcinoid and PNET. If the diagnosis of SCLC is confirmed, one should consider the very rare possibility of a combined SCLC with an adenocarcinoma component. A growing number of case reports have documented EGFR mutations in these cases raising the possibility of treatment with a tyrosine kinase inhibitor. ${ }^{44}$

\section{Other neuroendocrine tumors of the lung}

SCLC fits into the spectrum of neurocrine tumors of the lung as a high-grade tumor along with LCNEC and as a low-grade TC and intermediate-grade AC.
LCNEC comprises $\sim 3 \%$ of resected lung cancers and carcinoids represent $1-2 \%$ of all invasive lung malignancies with $\sim 10 \%$ representing AC. $^{28}$ The importance of these tumors is much greater than their relative infrequency, because they often come into the differential diagnosis with the much more common SCLC. Although these tumors are frequently discussed together as in this section, carcinoid tumors are only distantly related to highgrade SCLC and LCNEC with major differences in clinical, epidemiological, pathological and molecular features. . $^{3,12,45}$

The varied biological behavior of this spectrum of NE tumors is reflected by their differences in survival. TC has a 5-year overall survival of $>90 \%$ and for AC it ranges between 40 and $60 \%$. Survival data for LCNEC are mainly from series of surgically resected cases, which have shown similar poor survival to that of SCLC. ${ }^{12}$ However, a recent analysis of 1211 LCNEC from the SEER data suggests that LCNEC may have a more favorable overall and lung cancer-specific survival compared with SCLC in patients who received definitive surgery without radiation. ${ }^{46}$ These data suggest that the survival for LCNEC is more like other large cell carcinomas than SCLC, which may support maintaining this tumor as a variant of large cell carcinoma. ${ }^{46}$ Another epidemiological difference between SCLC and LCNEC and carcinoids is the strong association with heavy smoking in the former, which is lacking with TC and AC. ${ }^{12,45}$

\section{Large cell neuroendocrine carcinoma}

LCNEC is a high-grade non-small cell neuroendocrine carcinoma that meets the following criteria: (1) neuroendocrine morphology: organoid, palisading, trabecular or rosette-like growth patterns (Figure 9a); (2) non-small cell cytological features: large size, polygonal shape, low N/C ratio, coarse or vesicular 

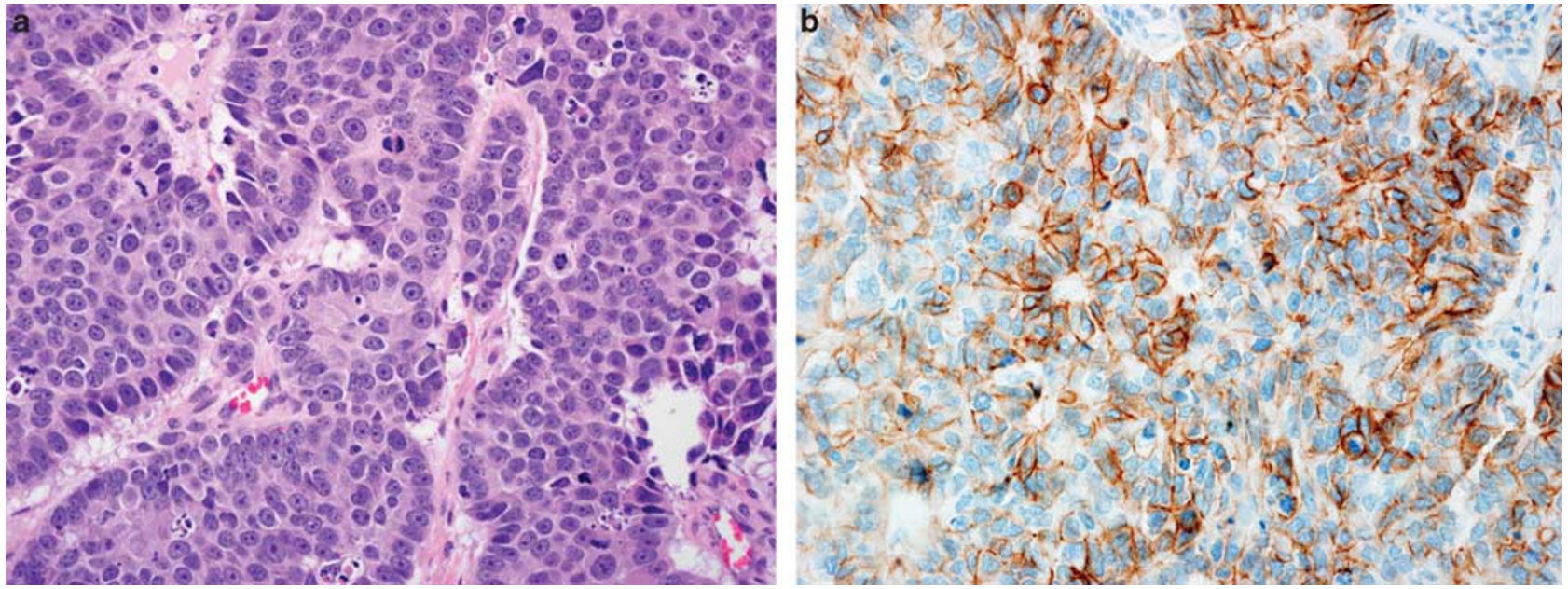

Figure 9 Large cell neuroendocrine carcinoma. (a) The tumor grows in organoid nests with peripheral palisading, rosette-like structures and prominent mitoses. Tumor cells have abundant cytoplasm, prominent nucleoli and an atypical mitosis. (b) CD56 stains many of the tumor cells.

nuclear chromatin and frequent nucleoli; (3) high mitotic rate $\left(\geq 11\right.$ per $\left.2 \mathrm{~mm}^{2}\right)$ with a mean of 60 mitoses per $2 \mathrm{~mm}^{2}$; (4) frequent necrosis; and (5) at least one positive neuroendocrine immunohistochemical marker or neuroendocrine granules by electron microscopy (Figure 9b). ${ }^{10,31}$ It is very difficult to diagnose LCNEC based on small biopsy specimens such as needle or bronchoscopic biopsy specimens as it is usually very difficult to be certain of the neuroendocrine morphology without a substantial sampling of the tumor. However, criteria have been proposed to diagnose LCNEC based on cytology. ${ }^{47}$ The term 'large cell carcinoma, with neuroendocrine morphology' can be used for tumors resembling LCNEC by light microscopy but lacking proof of neuroendocrine differentiation by electron microscopy or immunohistochemistry. ${ }^{10}$ The term 'combined LCNEC' is appropriate for those tumors containing components of other histological types of NSCLC, such as adenocarcinoma or squamous cell carcinoma. ${ }^{10}$ The main criteria for distinguishing SCLC from LCNEC are discussed above and summarized in Table 2.

\section{Typical and atypical carcinoid}

Both TC and AC are characterized histologically by a uniform population of tumor cells growing in an organoid pattern and having moderate eosinophilic, finely granular cytoplasm with finely granular nuclear chromatin (Figures 10a-c). A spectrum of histological patterns occur in carcinoids including spindle cell, trabecular, palisading, rosette-like, papillary, sclerosing papillary, glandular and follicular patterns. ${ }^{10}$ Unusual cytological features can occur such as oncocytic, acinic cell-like, signet-ring, mucin-producing or melanocytic features. ${ }^{31}$

ACs are defined as carcinoid tumors showing mitoses between 2 and 10 per $2 \mathrm{~mm}^{2}$ area of viable tumor (10 high power fields in certain microscopes) or the presence of necrosis (Figures $10 \mathrm{~b}$ and c). ${ }^{48}$ The presence of features such as pleomorphism, vascular invasion and increased cellularity is not as helpful in separating TC from AC. In TC, necrosis is absent and mitotic figures are rare $(<2$ per $\left.2 \mathrm{~mm}^{2}\right) .{ }^{31,48}$ Necrosis in AC usually is manifest by punctate foci within tumor nests (Figure 10b).

Carcinoid tumors stain for neuroendocrine markers such as chromogranin, synaptophysin and CD56. Reports of TTF-1 expression are variable with one study suggesting peripheral tumors are positive more frequently than central tumors. ${ }^{49}$

Both typical and atypical carcinoid tumors are histologically lower-grade tumors than SCLC and LCNEC as reflected by mitotic rates and proliferation rates. Mitotic rates are high in SCLC and LCNEC, and necrosis tends to be very extensive, but in AC. the rates are low with only up to 10 mitoses per $2 \mathrm{~mm}^{2}$ and necrosis tends to be focal. In a small crushed specimen, it may be difficult to identify mitoses. In SCLC, tumor cells also tend to have less cytoplasm than those of AC; thus the tumor appears more hyperchromatic. A low proliferation rate $(\leqslant 5 \%)$ is seen in TC by Ki-67 staining compared with AC in which it is usually between 5 and $20 \%{ }^{30,37,50,51}$ In small crushed biopsies, Ki-67 staining can be helpful in separating TC or AC from the-high-grade LCNEC or SCLC, which have very high proliferation rates (Figure 2C). ${ }^{30,50}$

Ki-67 can also be useful as it will be very high in SCLC (usually $>50-70 \%$ ), but low (usually $<5-$ $15 \%$ ) in carcinoids. ${ }^{30,37,51}$ Precise Ki-67 thresholds for TC vs AC are not established.

\section{Genetic alterations in SCLC and other pulmonary neuroendocrine tumors}

Our understanding of neuroendocrine lung tumors has been enhanced by genetic studies. Unfortunately, 

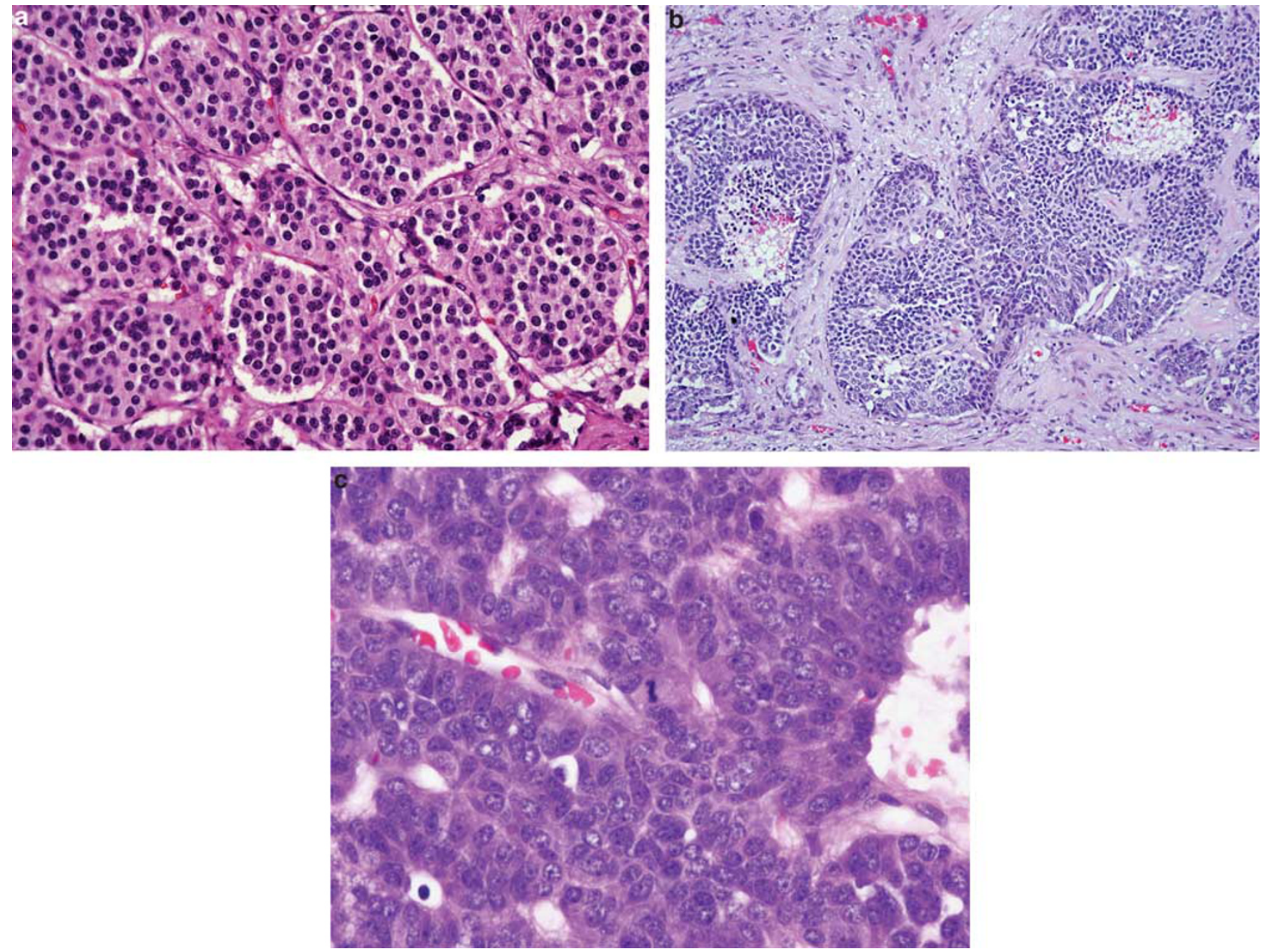

Figure 10 Carcinoid. (a) Typical carcinoid. This tumor shows an organoid nesting pattern of uniform cells with a moderate amount of eosinophilic cytoplasm and finely granular nuclear chromatin. (b) Atypical carcinoid shows a punctate focus necrosis within sheets and nests of carcinoid tumor cells. Cells have finely granular nuclear chromatin. (c) Atypical carcinoid shows single mitoses (center) in one tumor cell.

unlike adenocarcinoma in which molecular targets such as EGFR mutations have transformed therapeutic paradigms ${ }^{45}$ and recent discoveries have revealed promising targets such as DDR2 mutation and FRGF1 amplification for squamous cell carcinoma, no breakthroughs exist for SCLC and other pulmonary neuroendocrine tumors that have led to any effective novel therapies. ${ }^{52} \mathrm{~A}$ high percentage of SCLC and LCNEC shows genetic changes with fewer aberrations seen in carcinoids. It is not surprising that many similar genetic abnormalities would be found in SCLC and LCNEC as they are both high-grade neuroendocrine carcinomas. However, some genetic differences have been demonstrated between LCNEC and SCLC, ${ }^{23,53,54}$ as well as TC and AC. ${ }^{54,55}$ These findings support the concept that these tumors should continue to be classified separately.

Recent data have shown increased insulin-like growth factor 1 receptor protein expression and gene copy number in SCLC with a significant correlation between expression and copy number. ${ }^{56}$ Although not yet proven to be effective, IGF1R inhibitors are beginning to be tested in research trials for SCLC. ${ }^{56}$
SCLC and LCNEC show a high frequency of loss of heterozygosity (LOH) for 3p, RB, 5q21, 9p and p53 compared with TC and AC. ${ }^{54}$ Significantly more frequent $5 \mathrm{q} 21 \mathrm{LOH}$ was found in SCLC than in LCNEC, as well as in high-grade carcinomas than in carcinoids. In addition, in the spectrum from TC to AC and high-grade SCLC and LCNEC, increasing percentages of $\mathrm{P} 53$ abnormalities were demonstrated by immunohistochemistry, $\mathrm{LOH}$ and mutation analysis. ${ }^{54}$ No P53 mutations were found in TC with $25 \%$ in AC, $59 \%$ in LCNEC and $71 \%$ in SCLC. These data are comparable to other reports in high-grade neuroendocrine carcinomas with p53 expression ranging between 40 and $86 \%$ and P53 mutations from 27 to $59 \% .{ }^{50,57-61}$ In high-grade neuroendocrine tumors, Onuki et a ${ }^{54}$ found that $58 \%$ were $\mathrm{G}: \mathrm{C}$ to $\mathrm{T}: \mathrm{A}$ or other transversions and that G:C to T:A transversions are associated with bulky carcinogens found in cigarette smoke. This fits with the frequent heavy cigarette smoking history in LCNEC and SCLC patients. ${ }^{62}$ Interestingly in the few AC with mutations, these transversions were not present. This is consistent with the fact that AC patients have 
significantly less smoking histories than do LCNEC and SCLC patients. ${ }^{62} \mathrm{~A}$ single KRAS mutation was found in one LCNEC, which is not surprising because of the frequency of combined LCNEC and adenocarcinomas. ${ }^{54}$

The P16 ${ }^{\mathrm{INK} 4} /$ cyclin $\mathrm{D} 1 / \mathrm{Rb}$ pathway that is involved in the regulation of $\mathrm{G} 1$ arrest in the cell cycle is frequently affected in NE tumors. ${ }^{55,63}$ In SCLC, Rb loss is frequent in SCLC and LCNEC but not in TC and it can be found in $60 \%$ of AC. In high-grade tumors, there is an inverse relationship between $\mathrm{Rb}$ and $\mathrm{P} 16$, and in all neuroendocrine tumors, there is a direct relationship between cyclin $\mathrm{D} 1$ and $\mathrm{Rb}$, indicating that p16 and cyclin D1 act exclusively on the Rb pathway for cell-cycle regulation. ${ }^{55}$ Igarashi et al demonstrated overexpression of cyclin B1 in a high percentage of LCNEC and SCLC. These data demonstrate that the RB pathway of G1 arrest is consistently compromised in SCLC and LCNEC, but is intact in TC with intermediate aberrations in AC. ${ }^{55,63}$

The C-kit protein expression has been found in high-grade pulmonary neuroendocrine tumors. Frequent positive membranous/cytoplasmic expression in high-grade tumors with 77/44\% of LCNEC, 70/ $67 \%$ of SCLC was found by Pelosi et al ${ }^{64}$ but it was found in only $7 \%$ of carcinoid tumors. Araki and Casali et al. ${ }^{65,66}$ found C-kit staining in 55 and $61 \%$ of LCNEC, respectively. A significantly worse prognosis $(P=0.046)$ and a higher rate of recurrence (0.037) was found by Casali et $a l^{66}$ for patients with C-kit positive LCNEC. In contrast, neither Pelosi et $a l^{64}$ nor Araki et $a l^{65}$ found any prognostic significance to C-kit expression with LCNEC or SCLC.

$\mathrm{LOH}$ at chromosome 11q13, the site of the MEN1 gene is found in lung carcinoids from familial MEN1 patients. ${ }^{67}$ In addition, $\mathrm{LOH}$ at this locus and MEN1 gene mutations can be demonstrated in up to $36 \%$ of sporadic carcinoids, particularly AC. ${ }^{68}$ MEN mutations are very rare in LCNEC and they are not found in SCLC. ${ }^{68-70}$ In 1 of 13 LCNEC, Debelenko et $a l^{69}$ found a somatic frameshift in the MEN1 gene (1226delC), which represented the first mutation observed in a tumor not typically associated with MEN1. On the other allele, neither a deletion or mutation was detected, and wild-type mRNA sequence was expressed. This suggested that the typical two-hit mechanism of MEN1 gene inactivation had not taken place. ${ }^{69}$

\section{Acknowledgement}

The author would like to gratefully acknowledge Drs Hangjun Wang and Ronald Ghossein for help with generating Table 3 in the differential diagnosis of small cell carcinoma and basaloid carcinoma.

\section{Disclosure/conflict of interest}

The authors declare no conflict of interest.

\section{References}

1 Altekruse SF, Kosary CL, Krapcho M, et al. SEER Cancer Statistics Review, 1975-2007, National Cancer Institute.http://seer.cancer.gov/csr/1975_2007/ 2010. Ref Type: Internet Communication.

2 Travis WD, Travis LB, Devesa SS. Lung cancer [published erratum appears in Cancer 1995 Jun 15; 75(12):2979]. Cancer 1995;75:191-202.

3 Krug LM, Pietanza MC, Kris MG, et al. Small cell and other neuroendocrine tumors of the lung. In: DeVita VT, Lawrence TS, Rosenberg SA. (eds). DeVita, Hellman and Rosenberg's Cancer, Principle and Practice of Oncology, 9th edn. Wolters Kluwer; Lippincott Williams \& Wilkins: Philadelphia, 2011, pp 848-870.

4 Siegel R, Ward E, Brawley O, et al. Cancer statistics, 2011: the impact of eliminating socioeconomic and racial disparities on premature cancer deaths. CA Cancer J Clin 2011;61:212-236.

5 Goldstraw P. IASLC Staging Manual in Thoracic Oncology. 1st edn. International Association for the Study of Lung Cancer; Editorial Rx Press: Orange Park, FL, 2009.

6 Rusch VW, Appleman HD, Blackstone E, et al. Lung. In: Edge SB, Byrd DR, Compton CC, Fritz AG, Greene FL, Trotti A. (eds). AJCC Cancer Staging Manual, 7th edn. American Joint Commision on Cancer; Springer: Chicago, 2009, pp. 253-270.

7 Vallieres E, Shepherd FA, Crowley J, et al. The IASLC Lung Cancer Staging Project: proposals regarding the relevance of TNM in the pathologic staging of small cell lung cancer in the forthcoming (seventh) edition of the TNM classification for lung cancer. J Thorac Oncol 2009;4:1049-1059.

8 Kreisman H, Wolkove N, Quoix E. Small cell lung cancer presenting as a solitary pulmonary nodule. Chest 1992;101:225-231.

9 Gephardt GN, Grady KJ, Ahmad M, et al. Peripheral small cell undifferentiated carcinoma of the lung. Clinicopathologic features of 17 cases. Cancer 1988; 61:1002-1008.

10 Travis WD, Brambilla E, Müller-Hermelink HK, et al. Pathology and Genetics: Tumours of the Lung, Pleura, Thymus and Heart Vol 1. IARC: Lyon, 2004.

11 Nicholson SA, Beasley MB, Brambilla E. et al. Small cell lung carcinoma (SCLC): a clinicopathologic study of 100 cases with surgical specimens. Am J Surg Pathol 2002;26:1184-1197.

12 Travis WD. Advances in neuroendocrine lung tumors. Ann Oncol 2010;21(Suppl 7):vii65-vii71.

13 Azzopardi JG. Oat-cell carcinoma of the bronchus. J Pathol Bacteriol 1959;78:513-519.

14 Tsubota YT, Kawaguchi T, Hoso T, et al. A combined small cell and spindle cell carcinoma of the lung. Report of a unique case with immunohistochemical and ultrastructural studies. Am J Surg Pathol 1992;16:1108-1115.

15 Fraire AE, Johnson EH, Yesner R, et al. Prognostic significance of histopathologic subtype and stage in small cell lung cancer. Hum Pathol 1992;23:520-528.

16 Sehested M, Hirsch FR, Osterlind K, et al. Morphologic variations of small cell lung cancer. A histopathologic study of pretreatment and posttreatment specimens in 104 patients. Cancer 1986;57:804-807.

17 Vollmer RT. The effect of cell size on the pathologic diagnosis of small and large cell carcinomas of the lung. Cancer 1982;50:1380-1383. 
18 Bobos M, Hytiroglou P, Kostopoulos I, et al. Immunohistochemical distinction between merkel cell carcinoma and small cell carcinoma of the lung. Am J Dermatopathol 2006;28:99-104.

19 Chu PG, Wu E, Weiss LM. Cytokeratin 7 and cytokeratin 20 expression in epithelial neoplasms: a survey of 435 cases. Mod Pathol 2000;13:962-972.

20 Maleki Z. Diagnostic issues with cytopathologic interpretation of lung neoplasms displaying high-grade basaloid or neuroendocrine morphology. Diagn Cytopathol 2011;39:159-167.

21 Guinee Jr DG, Fishback NF, Koss MN, et al. The spectrum of immunohistochemical staining of smallcell lung carcinoma in specimens from transbronchial and open-lung biopsies. Am J Clin Pathol 1994;102: 406-414.

22 Kontogianni K, Nicholson AG, Butcher D, et al. CD56: a useful tool for the diagnosis of small cell lung carcinomas on biopsies with extensive crush artefact. J Clin Pathol 2005;58:978-980.

23 Hiroshima K, Iyoda A, Shida T, et al. Distinction of pulmonary large cell neuroendocrine carcinoma from small cell lung carcinoma: a morphological, immunohistochemical, and molecular analysis. Mod Pathol 2006;19:1358-1368.

24 Folpe AL, Gown AM, Lamps LW, et al. Thyroid transcription factor-1: immunohistochemical evaluation in pulmonary neuroendocrine tumors. Mod Pathol 1999;12:5-8.

25 Sturm N, Rossi G, Lantuejoul S, et al. Expression of thyroid transcription factor-1 in the spectrum of neuroendocrine cell lung proliferations with special interest in carcinoids. Hum Pathol 2002;33:175-182.

26 Sturm N, Lantuejoul S, Laverriere MH, et al. Thyroid transcription factor 1 and cytokeratins 1, 5, 10, 14 (34betaE12) expression in basaloid and large-cell neuroendocrine carcinomas of the lung. Hum Pathol 2001;32:918-925.

27 Travis WD. Neuroendocrine lung tumors. Path Case Rev 2006;11:235-242.

28 Travis WD. Lung tumours with neuroendocrine differentiation. Eur J Cancer 2009;45(Suppl 1):251-266.

29 Agoff SN, Lamps LW, Philip AT, et al. Thyroid transcription factor-1 is expressed in extrapulmonary small cell carcinomas but not in other extrapulmonary neuroendocrine tumors. Mod Pathol 2000; 13:238-242.

30 Pelosi G, Rodriguez J, Viale G, et al. Typical and atypical pulmonary carcinoid tumor overdiagnosed as small-cell carcinoma on biopsy specimens: a major pitfall in the management of lung cancer patients. Am J Surg Pathol 2005;29:179-187.

31 Travis WD, Linnoila RI, Tsokos MG, et al. Neuroendocrine tumors of the lung with proposed criteria for large-cell neuroendocrine carcinoma. An ultrastructural, immunohistochemical, and flow cytometric study of 35 cases. Am J Surg Pathol 1991;15:529-553.

32 Vollmer RT, Ogden L, Crissman JD. Separation of small-cell from non-small-cell lung cancer. The Southeastern Cancer Study Group pathologists' experience. Arch Pathol Lab Med 1984;108:792-794.

33 Feld R, Sagman U, Leblanc M. Staging and prognostic factors for small cell carcinoma. In: Pass HI, Mitchell JB, Johnson DH, Turrisi AT, Minna JD. (eds). Lung Cancer, Principles and Practice, 2nd edn. Lippincott Williams \& Wilkins: Philadelphia, 2000, pp. 612-627.
34 World Health Organization.. Histological Typing of Lung Tumors, 2nd edn. World Health Organization: Geneva, 1981.

35 Marchevsky AM, Gal AA, Shah S, et al. Morphometry confirms the presence of considerable nuclear size overlap between 'small cells' and 'large cells' in highgrade pulmonary neuroendocrine neoplasms. Am J Clin Pathol 2001;116:466-472.

36 Viberti L, Bongiovanni M, Croce S, et al. 34 betaE12 cytokeratin immunodetection in the differential diagnosis of small cell tumors of lung. Int J Surg Pathol 2000;8:317-322.

37 Tsuta K, Liu DC, Kalhor N, et al. Using the mitosisspecific marker anti-phosphohistone h3 to assess mitosis in pulmonary neuroendocrine carcinomas. Am J Clin Pathol 2011;136:252-259.

38 Devoe K, Weidner N. Immunohistochemistry of small round-cell tumors [in process citation]. Semin Diagn Pathol 2000;17:216-224.

39 Llombart-Bosch A, Machado I, Navarro S, et al. Histological heterogeneity of Ewing's sarcoma/PNET: an immunohistochemical analysis of 415 genetically confirmed cases with clinical support. Virchows Arch 2009;455:397-411.

40 Chan JK, Suster S, Wenig BM, et al. Cytokeratin 20 immunoreactivity distinguishes Merkel cell (primary cutaneous neuroendocrine) carcinomas and salivary gland small cell carcinomas from small cell carcinomas of various sites. Am J Surg Pathol 1997;21: 226-234.

41 Leech SN, Kolar AJ, Barrett PD, et al. Merkel cell carcinoma can be distinguished from metastatic small cell carcinoma using antibodies to cytokeratin 20 and thyroid transcription factor 1. J Clin Pathol 2001;54: 727-729.

42 Shah IA, Netto D, Schlageter MO, et al. Neurofilament immunoreactivity in Merkel-cell tumors: a differentiating feature from small-cell carcinoma. Mod Pathol 1993;6:3-9.

43 Brambilla E, Moro D, Gazzeri S, et al. Cytotoxic chemotherapy induces cell differentiation in smallcell lung carcinoma. J Clin Oncol 1991;9:50-61.

44 Shiao TH, Chang YL, Yu CJ, et al. Epidermal growth factor receptor mutations in small cell lung cancer: a brief report. J Thorac Oncol 2011;6:195-198.

45 Travis WD, Brambilla E, Noguchi M, et al. The new IASLC/ATS/ERS international multidisciplinary lung adenocarcinoma classification. J Thoracic Oncol 2011;6:244-285.

46 Varlotto JM, Medford-Davis LN, Recht A, et al. Should large cell neuroendocrine lung carcinoma be classified and treated as a small cell lung cancer or with other large cell carcinomas? J Thorac Oncol 2011;6:1050-1058.

47 Wiatrowska BA, Krol J, Zakowski MF. Large-cell neuroendocrine carcinoma of the lung: proposed criteria for cytologic diagnosis. Diagn Cytopathol 2001;24:58-64.

48 Travis WD, Rush W, Flieder DB, et al. Survival analysis of 200 pulmonary neuroendocrine tumors with clarification of criteria for atypical carcinoid and its separation from typical carcinoid. Am J Surg Pathol 1998;22:934-944.

49 Du EZ, Goldstraw P, Zacharias J, et al. TTF-1 expression is specific for lung primary in typical and atypical carcinoids: TTF-1-positive carcinoids are predominantly in peripheral location. Hum Pathol 2004;35: 825-831. 
50 Iyoda A, Hiroshima K, Moriya Y, et al. Pulmonary large cell neuroendocrine carcinoma demonstrates high proliferative activity. Ann Thorac Surg 2004;77: 1891-1895.

51 Skov BG, Holm B, Erreboe A, et al. ERCC1 and Ki67 in small cell lung carcinoma and other neuroendocrine tumors of the lung: distribution and impact on survival. J Thorac Oncol 2010;5:453-459.

52 D’Angelo SP, Pietanza MC. The molecular pathogenesis of small cell lung cancer. Cancer Biol Ther 2010;10:1-10.

53 Nasgashio R, Sato Y, Matsumoto T, et al. The balance between the expressions of hASH1 and HES1 differs between large cell neuroendocrine carcinoma and small cell carcinoma of the lung. Lung Cancer 2011; e-pub ahead of print.

54 Onuki N, Wistuba II, Travis WD, et al. Genetic changes in the spectrum of neuroendocrine lung tumors. Cancer 1999;85:600-607.

55 Beasley MB, Lantuejoul S, Abbondanzo S, et al. The $\mathrm{P} 16 /$ cyclin $\mathrm{D} 1 / \mathrm{Rb}$ pathway in neuroendocrine tumors of the lung. Hum Pathol 2003;34:136-142.

56 Badzio A, Wynes MW, Dziadziuszko R, et al. Increased insulin-like growth factor 1 receptor protein expression and gene copy number in small cell lung cancer. J Thorac Oncol 2010;5:1905-1911.

57 Brambilla E, Negoescu A, Gazzeri S, et al. Apoptosisrelated factors p53, Bcl2, and Bax in neuroendocrine lung tumors. Am J Pathol 1996;149:1941-1952.

58 Hiroshima K, Iyoda A, Shibuya K, et al. Genetic alterations in early-stage pulmonary large cell neuroendocrine carcinoma. Cancer 2004;100:1190-1198.

59 Jiang SX, Kameya T, Shinada J, et al. The significance of frequent and independent p53 and bcl-2 expression in large-cell neuroendocrine carcinomas of the lung. Mod Pathol 1999;12:362-369.

60 Przygodzki RM, Finkelstein SD, Langer JC, et al. Analysis of p53, K-ras-2, and C-raf-1 in pulmonary neuroendocrine tumors. Correlation with histological subtype and clinical outcome. Am J Pathol 1996;148: 1531-1541.

61 Sampietro G, Tomasic G, Collini P, et al. Gene product immunophenotyping of neuroendocrine lung tumors. No linking evidence between carcinoids and small-cell lung carcinomas suggested by multivariate statistical analysis. Appl Immunohistochem Mol Morphol 2000;8:49-56.
62 Hollstein M, Sidransky D, Vogelstein B, et al. p53 mutations in human cancers. Science 1991;253:49-53.

63 Igarashi T, Jiang SX, Kameya T, et al. Divergent cyclin B1 expression and Rb/p16/cyclin D1 pathway aberrations among pulmonary neuroendocrine tumors. Mod Pathol 2004;17:1259-1267.

64 Pelosi G, Masullo M, Leon ME, et al. CD117 immunoreactivity in high-grade neuroendocrine tumors of the lung: a comparative study of 39 large-cell neuroendocrine carcinomas and 27 surgically resected small-cell carcinomas. Virchows Arch 2004;445:449-455.

65 Araki K, Ishii G, Yokose T, et al. Frequent overexpression of the c-kit protein in large cell neuroendocrine carcinoma of the lung. Lung Cancer 2003;40:173-180.

66 Casali C, Stefani A, Rossi G, et al. The prognostic role of c-kit protein expression in resected large cell neuroendocrine carcinoma of the lung. Ann Thorac Surg 2004;77:247-252.

67 Dong Q, Debelenko LV, Chandrasekharappa SC, et al. Loss of heterozygosity at 11q13: analysis of pituitary tumors, lung carcinoids, lipomas, and other uncommon tumors in subjects with familial multiple endocrine neoplasia type 1. J Clin Endocrinol Metab 1997;82:1416-1420

68 Debelenko LV, Brambilla E, Agarwal SK, et al. Identification of MEN1 gene mutations in sporadic carcinoid tumors of the lung. Hum Mol Genet 1997;6: 2285-2290.

69 Debelenko LV, Swalwell JI, Kelley MJ, et al. MEN1 gene mutation analysis of high-grade neuroendocrine lung carcinoma. Genes Chromosomes Cancer 2000;28: 58-65.

70 Travis WD, Gal AA, Colby TV, et al. Reproducibility of neuroendocrine lung tumor classification. Hum Pathol 1998;29:272-279.

71 Kreyberg L. Histological lung cancer types. Acta Pathol Microbiol Scand [A] 1962;157:1.

72 World Health Organization.. Histological Typing of Lung Tumours, 1st edn. World Health Organization: Geneva, 1967.

73 Hirsch FR, Matthews MJ, Aisner S, et al. Histopathologic classification of small cell lung cancer. Changing concepts and terminology. Cancer 1988;62:973-977.

74 Travis WD, Colby TV, Corrin B, , et al., in collaboration with L.H.. Sobin and Pathologists from 14 Countries. Histological Typing of Lung and Pleural Tumors, 3rd edn. Springer: Berlin, 1999. 